\title{
Single gold nanoparticles counter: An ultrasensitive detection platform for homogenous immunoassays and DNA hybridization assays
}

\author{
Chao Xie, Fagong Xu, Xiangyi Huang, Chaoqing Dong and Jicun Ren*
}

\begin{abstract}
College of Chemistry \& Chemical Engineering, State Key Laboratory of Metal Matrix Composites, Shanghai Jiaotong University, 800 Dongchuan Road, Shanghai, 200240, P. R. China.

E-mail: jicunren@sjtu.edu.cn
\end{abstract}

\section{Supporting methods:}

Synthesis of gold nanoparticles (GNPs). GNPs were synthesized by reduction of the $\mathrm{HAuCl}_{4}$ solution with sodium citrate. ${ }^{1}$ Briefly, $100 \mathrm{~mL}$ of $0.01 \%(\mathrm{w} / \mathrm{v})$ of the $\mathrm{HAuCl}_{4}$ solution was heated to boiling for 15 minutes, and then $1 \%(\mathrm{w} / \mathrm{v})$ sodium citrate solution was added. The volume added depended on the requirement size of GNPs, and $1 \mathrm{~mL}$ of sodium citrate solution was needed for $36 \mathrm{~nm}$ GNPs. Heating continued for 15 minutes after the solution color remained unchanged. After cooling down to room temperature, the prepared GNPs stock solution was stored at $4{ }^{\circ} \mathrm{C}$ for further use. The concentration of GNPs was calculated according to the reference. ${ }^{2}$ GNPs were further purified and concentrated by centrifugation (Beckman Coulter, USA) 2 times at 2,500 rpm for 30 min (washing buffer: 0.01 M PBS, pH 7.4) prior to further use.

ELISA method (contrast experiments). To investigate the reliability of our method, the human sera were analyzed with ELISA method according to the operational manuals of ELISA kits. Briefly, $50 \mu \mathrm{L}$ antigen or human serum samples were added to the wells of the ELISA plate, and incubated at $37^{\circ} \mathrm{C}$ for 
$20 \mathrm{~min}$. The plates were emptied and washed four times with wash buffer (100 $\mathrm{mM}$ phosphate buffer, $150 \mathrm{mM} \mathrm{NaCl}, 0.2 \% \mathrm{BSA}$ and $0.05 \%$ Tween 20 ). Fifty $\mu \mathrm{L}$ enzyme-labeled antibody solution was added to each well and incubated at $37{ }^{\circ} \mathrm{C}$ for $20 \mathrm{~min}$. The plates were emptied again and washed three times with the wash buffer. The color development reagents were added and the color intensities were measured by UV absorption spectroscopy at $450 \mathrm{~nm}$ wavelength. The positive linear relationship between the color intensities and antigen concentrations was obtained.

Assay of thrombin by capillary electrophoresis (contrast experiments). The assay of thrombin by capillary electrophoresis (CE) was preformed according to the protocol of the reference..$^{3-5}$ In this work, a carboxyfluorescein-labeled 29-mer aptamer (F29-mer) was used, and an affinity CE with LIF detection method was established for quantitative analysis of thrombin based on the high affinity between anti-thrombin aptamer (F29-mer) and thrombin. F29-mer was mixed with thrombin in the running buffer (containing 2.5\% (v/v) serum) and incubated for $30 \mathrm{~min}$ at room temperature. Finally, the aptamer was $50 \mathrm{nM}$ and thrombin was from 0 to $400 \mathrm{nM}$. The running buffer was $2 \times \mathrm{TG}$ (TG containing $25 \mathrm{mM}$ Tris, $192 \mathrm{mM}$ glycine, $\mathrm{pH}$ 8.5). All capillary electrophoresis experiments were performed using a P/ACE MDQ CE equipment (Beckman Coulter, Flulerton, CA, USA) with an LIF detector ( $\lambda_{\text {ex }} / \lambda_{\text {em }}$ : $488 / 520 \mathrm{~nm}$ ). Fused-silica capillaries (Yongnian Optical Fiber, Hebei, China) of $30 \mathrm{~cm}$ length ( $20 \mathrm{~cm}$ to the detector) with an $75 \mu \mathrm{m}$ inner diameter and $360 \mu \mathrm{m}$ outer diameter were used. Following each electrophoresis run, the capillary was rinsed with $1 \mathrm{M} \mathrm{HCl}, \mathrm{H}_{2} \mathrm{O}, 1 \mathrm{M} \mathrm{NaOH}$, and running buffer for 2 min in turn. Samples were introduced by hydrodynamic injection at $0.3 \mathrm{psi}$ for $5 \mathrm{~s}$, and separated at 18 $\mathrm{kV}$. The data were recorded with 32 Karat software (version 4.0, Beckman Coutler). Assay of every sample was repeated three times. The human sera or the activated plasma samples were prepared by diluting human sera or activated plasma with running buffer to reach a final concentration of $2.5 \%(\mathrm{v} / \mathrm{v})$. An aliquot $(50 \mu \mathrm{L})$ of the sample was incubated at $25{ }^{\circ} \mathrm{C}$ for 30 min with $50 \mathrm{nM}$ of fluorescently labeled aptamer for thrombin and another $5 \mu \mathrm{M}$ of a non-specific and non-fluorescent 29-mer oligonucleotide. The non-specific oligonucleotide was used to reduce the interference from the sera or plasma matrix. The positive linear relationship between the peak area of thrombin-F29 mer complex and the thrombin 
concentration was obtained.

The theoretical calculation of photon burst counts. The photon burst counts are associated with the detection volume, the average lateral transit time and the probability $\left(P_{m}\right)$ of single GNPs within the detection volume, and the measurement time. The photon burst counts were estimated as follows. Firstly, the detection volume and the structure parameters of the focused laser beam were determined by fluorescence correction spectroscopy (FCS) with a 1nM Alexa 647 solution as standard substance (diffusion coefficient: $2.8 \times 10^{-6} \mathrm{~cm}^{2} / \mathrm{s}$ in water) ${ }^{6}$. The obtained horizontal radius $\omega_{0}$ and axial radius $Z_{0}$ of the focused laser beam were $0.28 \pm 0.01 \mu \mathrm{m}$ and $2.06 \pm 0.04 \mu \mathrm{m}$ respectively, and thus the detection volume of $0.9 \pm 0.05 \mathrm{fL}$ was obtained based on the formula $V=\pi^{\frac{3}{2}} \omega_{0}^{2} Z_{0}{ }^{7,8}$. Secondly, the diffusion coefficient $D$ of the $36 \mathrm{~nm}$ GNPs was obtained to be $1.36 \times 10^{-11} \mathrm{~m}^{2} / \mathrm{s}$ according to the Stokes-Einstein relation $D=k \cdot T /\left(6 \pi \cdot \eta \cdot R_{h}\right)$. Where, $k$ is Boltzmann constant $\left(1.38 \times 10^{-23} \mathrm{~J} \cdot \mathrm{K}^{-1} \cdot \mathrm{mol}^{-1}\right), T$ is the absolute temperature, $\eta$ is the viscosity of the solvent, and $R_{h}$ is the hydrodynamic radius of GNPs (here $R_{h}=36$ $\mathrm{nm})$. The average lateral transit time $\tau_{D}$ is calculated to be $1.4 \mathrm{~ms}$ on the basis of $\tau_{D}=\omega_{0}{ }^{2} /(4 \cdot D)$. Thirdly, the probability $\left(P_{m}\right)$ of single GNPs within the detection volume of $0.9 \mathrm{fL}$ is calculated to be $8.4 \%$ when the concentration of GNPs is $0.17 \mathrm{nM}$ according to Poisson statistics.

Based on the above calculation, we evaluated the photon burst counts (n) of $36 \mathrm{~nm}$ GNPs to be about 7200 in the detection volume of $0.9 \mathrm{fL}$ when the concentration of GNPs was $0.17 \mathrm{nM}$ and the measured time was $120 \mathrm{~s}$, based on the equation: $\mathrm{n}=\left(120 / \tau_{D}\right) \times P_{m}$. In this case, the measured result was about 2500 burst counts for $1 \mathrm{~ms}$ bin time, which were basically in agreement with the calculated result. The deviation between the measured and calculated results mainly originated from in the inaccurate concentration of GNPs and Gaussian profile of the focused laser beam.

\section{References}

(1) Freeman, R. G.; Hommer, M. B.; Grabar, K. C.; Jackson, M. A.; Natan, M. J. J. Phys. Chem. 1996, $100,718-724$. 
(2) Xu, C. S.; Cang, H.; Montiel, D.; Yang, H. J Phys. Chem. C 2007, 111, 32-35.

(3) Otsuka, H.; Akiyama, Y.; Nagasaki, Y.; Kataoka, K. J. Am. Chem. Soc.2001, 123, 8226-8230.

(4) Zhang, H.; Li, X. F.; Le, X. C. J. Am. Chem. Soc.2008, 130, 34-35.

(5) Li, Y.; Guo, L.; Zhang, F.; Zhang, Z.; Tang, J.; Xie, J. Electrophoresis 2008, 29, 2570-2577.

(6) Uyeda, H. T.; Medintz, I. L.; Jaiswal, J. K.; Simon, S. M.; Mattoussi, H. J. Am. Chem. Soc.2005, $127,3870-3878$.

(7) Foldes-Papp, Z.; Demel, U.; Tilz, G. P. J. Immunol. Methods 2002, 260, 117-124.

(8) Rarbach, M.; Kettling, U.; Koltermann, A.; Eigen, M. Methods 2001, 24, 104-116. 
Supporting Figures:
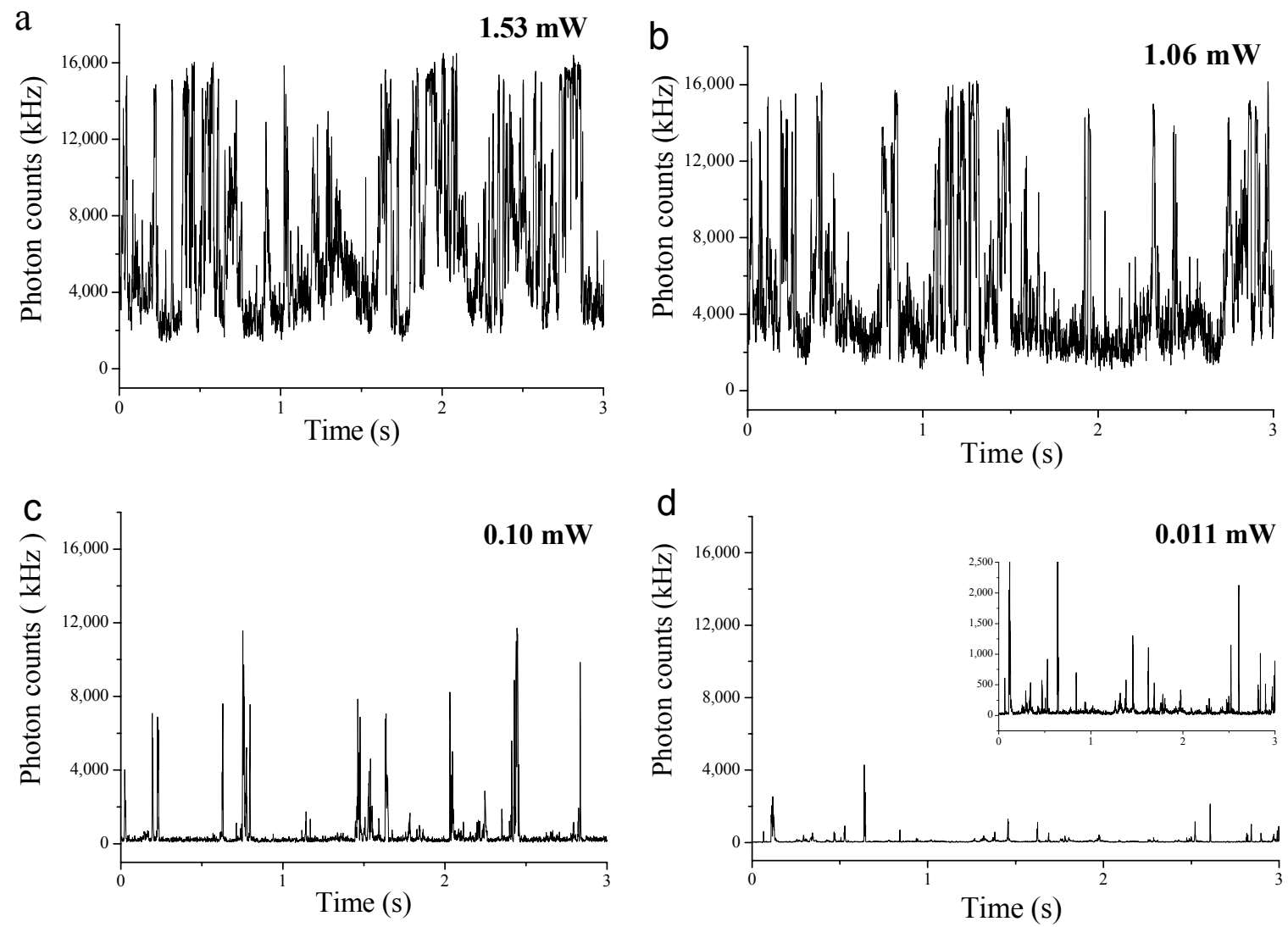

Figure S1. Typical photon burst traces of GNPs solution. The concentration of GNPs was $1.7 \times 10^{-10} \mathrm{M}$, and the size was $36 \mathrm{~nm}$. The laser illumination powers was $1.53 \mathrm{~mW}(\mathrm{a}), 1.06 \mathrm{~mW}(\mathrm{~b}), 0.10 \mathrm{~mW}$ (c) and $0.011 \mathrm{~mW}(\mathrm{~d})$, respectively. The wavelength of the laser beam was $632.8 \mathrm{~nm}$. The signal overflow of GNPs was observed under higher laser power (about $1 \mathrm{~mW}$ ). The inset in the Figure $\mathrm{d}$ is an enlarged figure of Figure $d$. The ratio of signal to noise is the highest at $0.10 \mathrm{~mW}$, and thus we chose $0.10 \mathrm{~mW}$ in following experiments. 

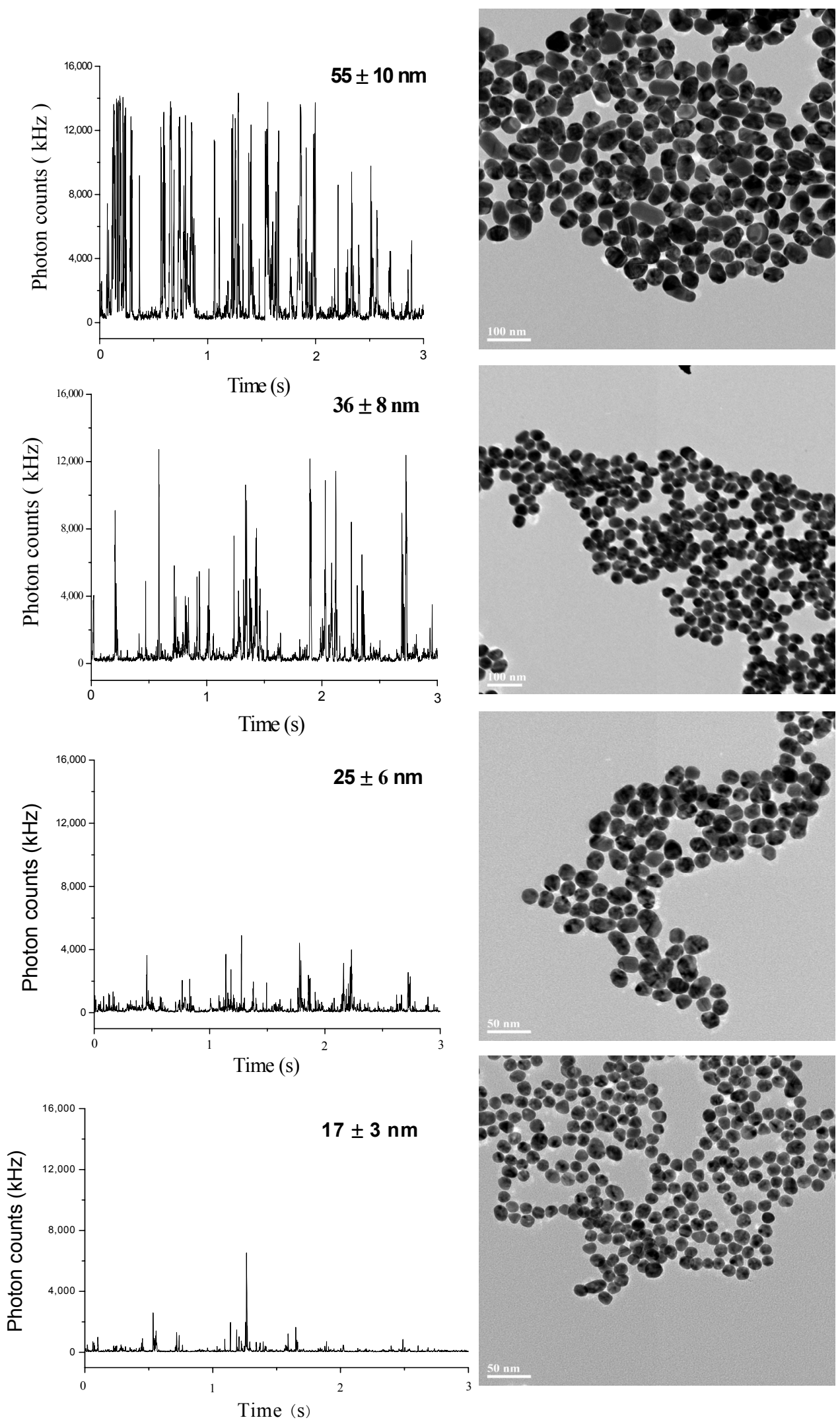

Figure S2. Photon burst traces of different size GNPs (left) and their transmission electron microscope (TEM) images (right). GNPs diameters are $55 \pm 10 \mathrm{~nm}, 36 \pm 4 \mathrm{~nm}, 25 \pm 6 \mathrm{~nm}$ and $17 \pm 3 \mathrm{~nm}$, respectively. The concentration of GNPs are $4.7 \times 10^{-11}, 1.7 \times 10^{-10}, 5.0 \times 10^{-11}$ and $1.6 \times 10^{-9} \mathrm{M}$, respectively. These 
results show that the intensity of photon bursts increase sharply with the diameters of GNPs. The signal overflow of $55 \pm 10 \mathrm{~nm}$ GNPs was observed in our detection system. Furthermore, we found that $55 \mathrm{~nm}$ GNPs (or bigger) was not very stable as $36 \mathrm{~nm}$ GNPs in the storage process. Therefore, $36 \mathrm{~nm}$ GNPs was chosen in our experiments. 


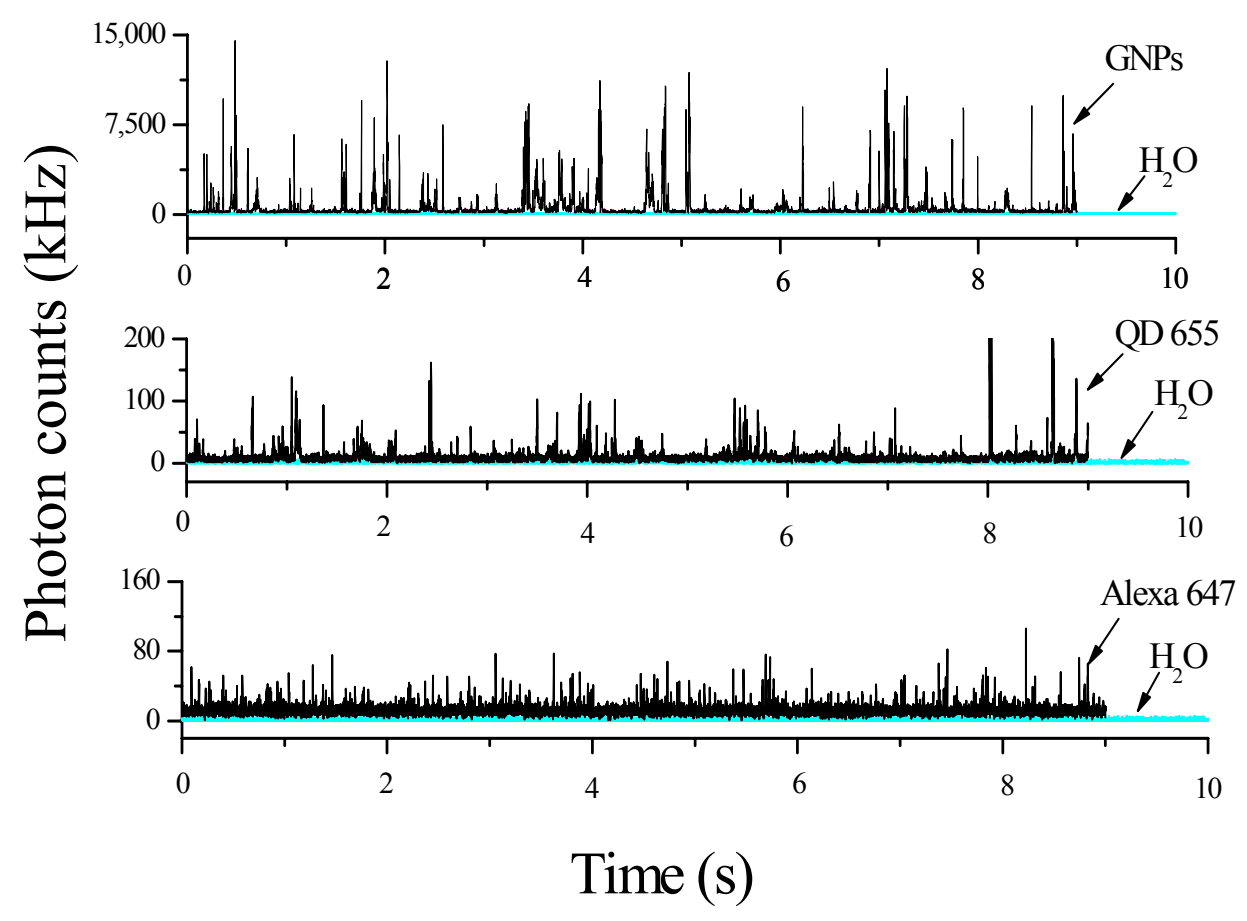

Figure S3. A comparison of the photon burst traces of gold nanoparticles (GNPs, $36 \mathrm{~nm}$ ), quantum dots (QDs 655) and Alexa 647. GNPs concentration was $1.7 \times 10^{-10} \mathrm{M}$, QDs concentration (the emission wavelength of $655 \mathrm{~nm}$ ) was $5.0 \times 10^{-11} \mathrm{M}$, and Alexa 647 concentration was $1.0 \times 10^{-10} \mathrm{M}$. Laser excitation power was $0.10 \mathrm{~mW}$. The fluorescence of QD 655 and Alexa 647 was filtered by a band-pass filter (660DF50, Omega Optical, USA). As shown in this figure, the photon burst intensity of single GNPs was several tens to hundreds times higher than that of QDs and organic dyes. 


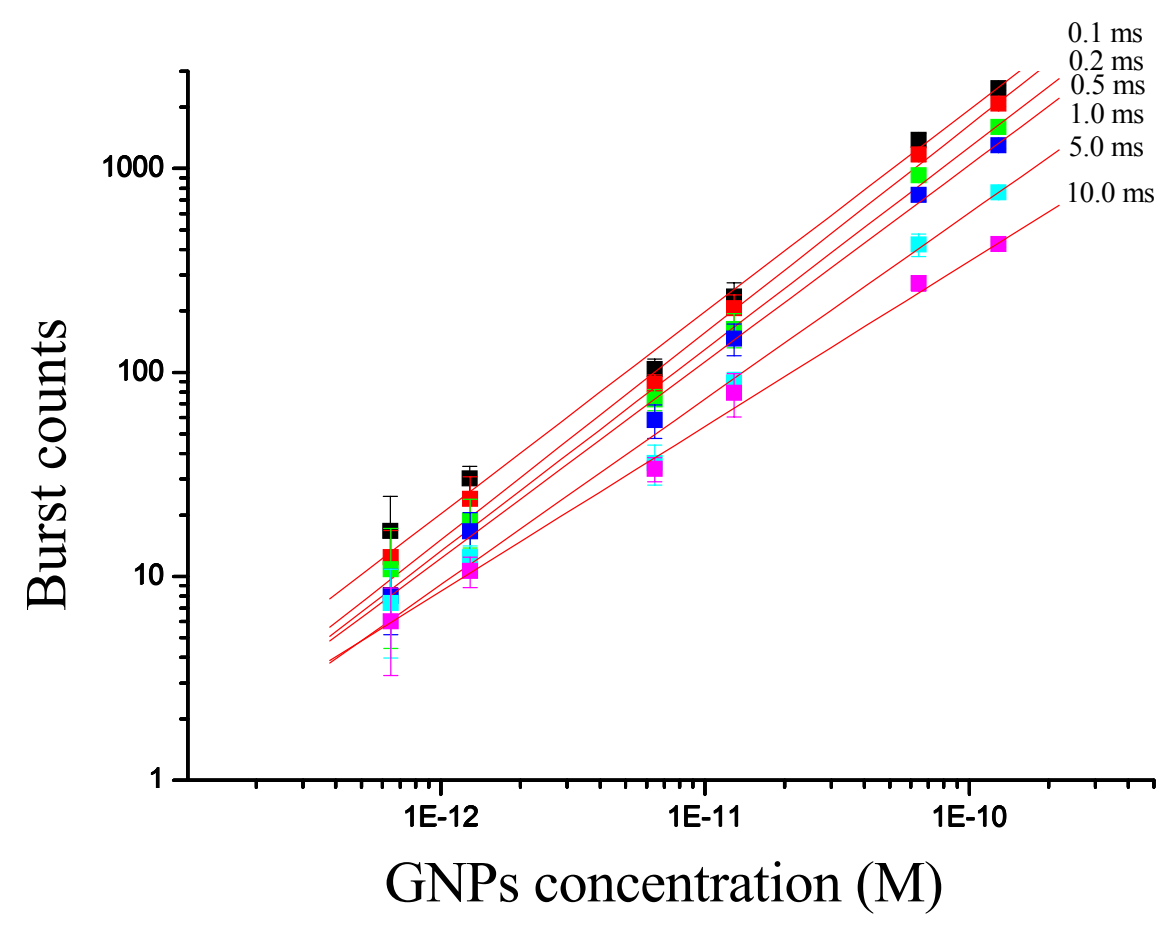

Figure S4. The linear relationship of the burst counts and GNP concentration. There are no distinguishable differences in the linearity and the slope of the curves at our experiment range ( $0.1 \mathrm{~ms}$, $0.2 \mathrm{~ms} 0.5 \mathrm{~ms}, 1 \mathrm{~ms}, 5 \mathrm{~ms}$ and $10 \mathrm{~ms}$ ). We chose $1 \mathrm{~ms}$ as the bin time for following experiment. 


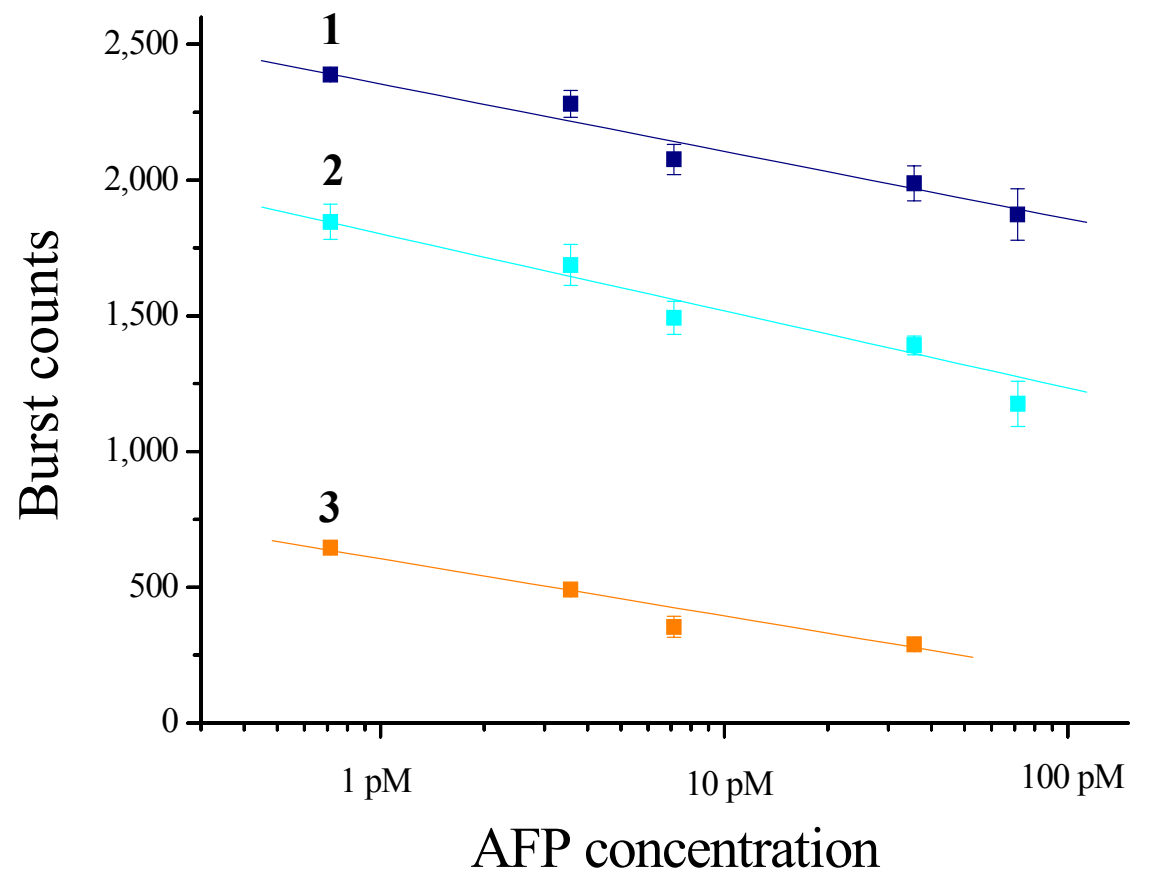

Figure S5. Titration curves of alpha fetal protein (AFP) with different antibody-GNPs conjugate concentrations. Lines 1, 2 and 3 show the antibody-GNPs conjugates concentrations of $285 \mathrm{pM}, 143 \mathrm{pM}$, and $57 \mathrm{pM}$, respectively. We observed no significant differences in the slopes of three calibration curves, which showed that the concentrations of antibody-GNPs conjugates had no significant effect on the sensitivity of this assay under our experimental conditions. 


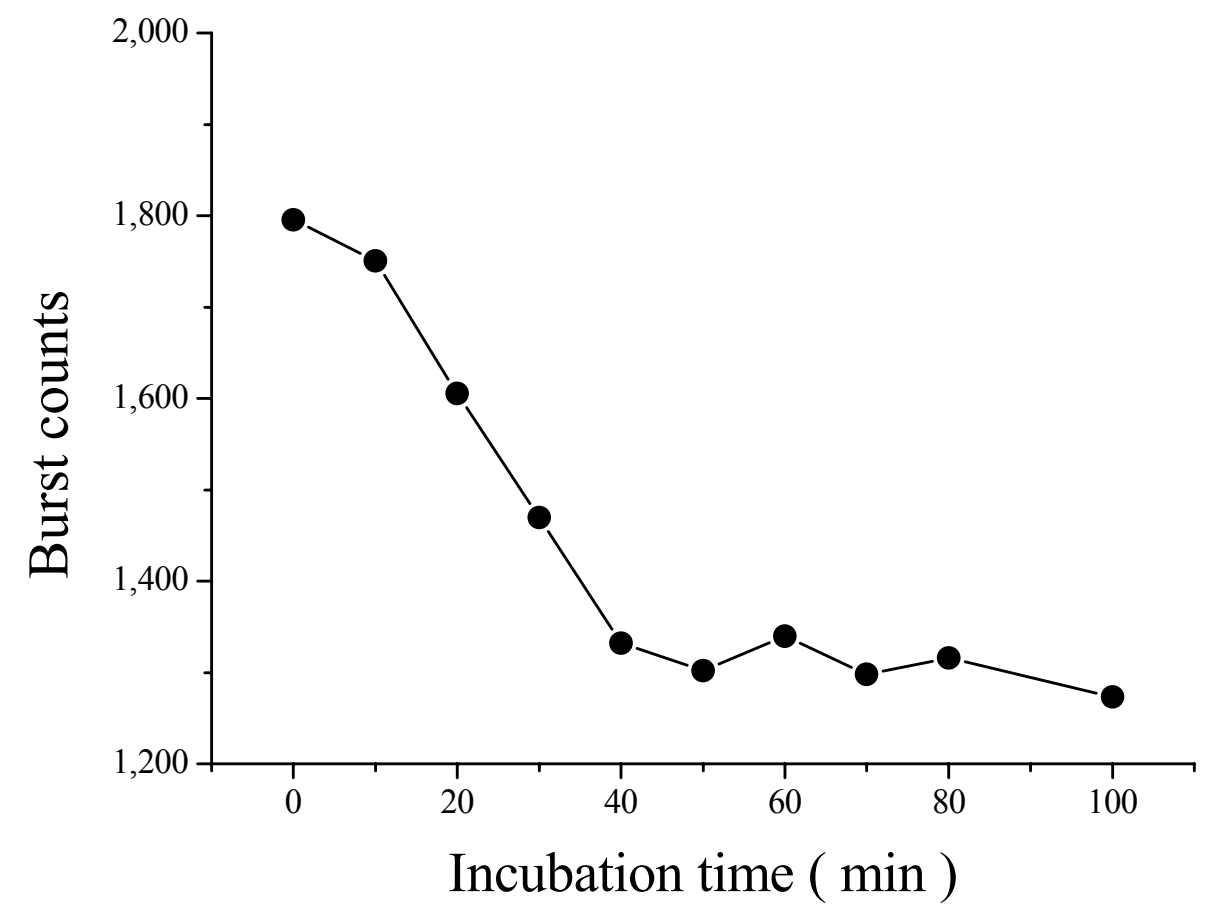

Figure S6. The curve of burst counts versus immunoassay reaction time. In this study, $10 \mu \mathrm{L}$ of $0.25 \mathrm{nM}$ GNPs-anti-AFP-1 conjugate solution, $10 \mu \mathrm{L}$ of $0.25 \mathrm{nM}$ GNPs-anti-AFP-2 conjugate solution and $20 \mu \mathrm{L}$ of 0.01 M PBS buffer ( $\mathrm{pH}=7.4$ ) were added into a $200 \mu \mathrm{L}$ sterilized polypropylene tube respectively and mixed well. Ten $\mu \mathrm{L}$ of $10 \mathrm{ng} / \mathrm{mL}$ AFP antigen standard solution was added, mixed well and incubated at $37{ }^{\circ} \mathrm{C}$ for different reaction time. The burst counts of samples were measured by SGNPC method. As shown in this figure, the immune reaction completed after 40 minutes incubation. In the following experiments, the incubation time was $1 \mathrm{~h}$. 
a

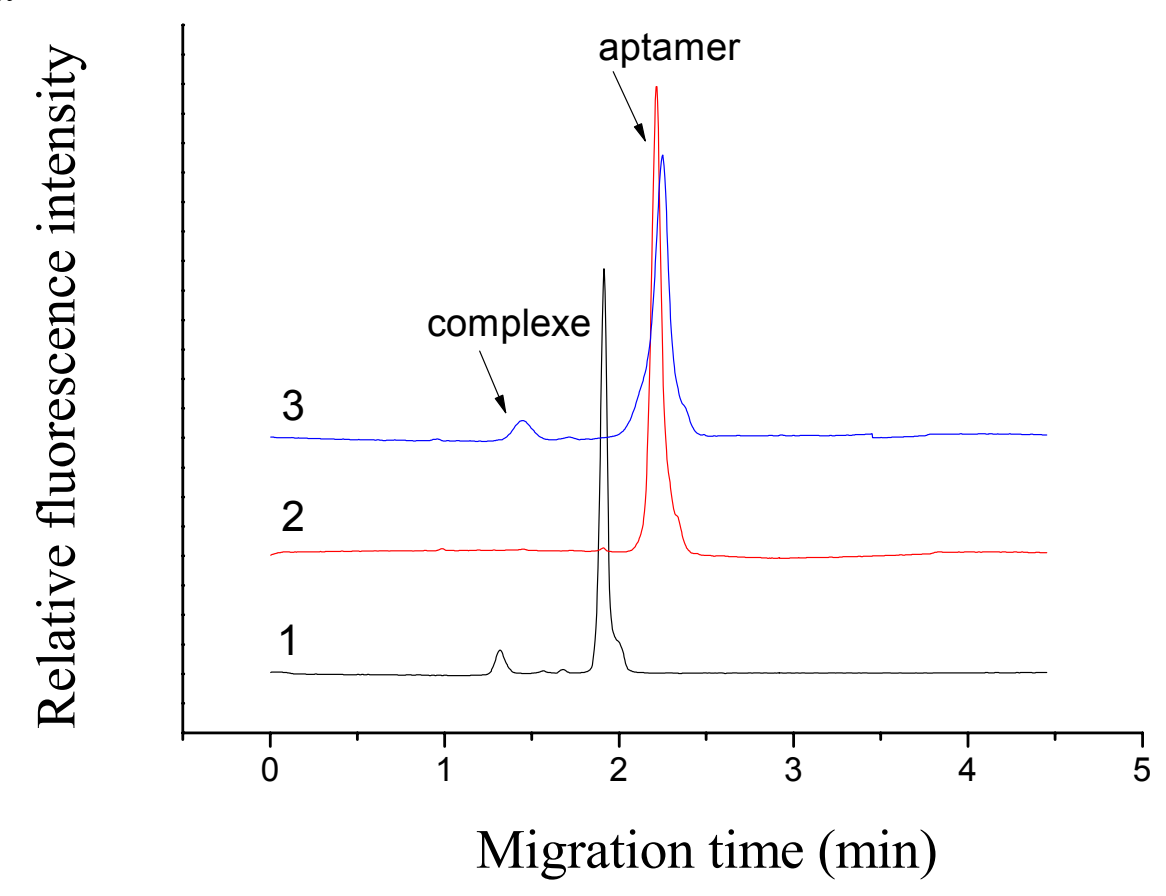

b

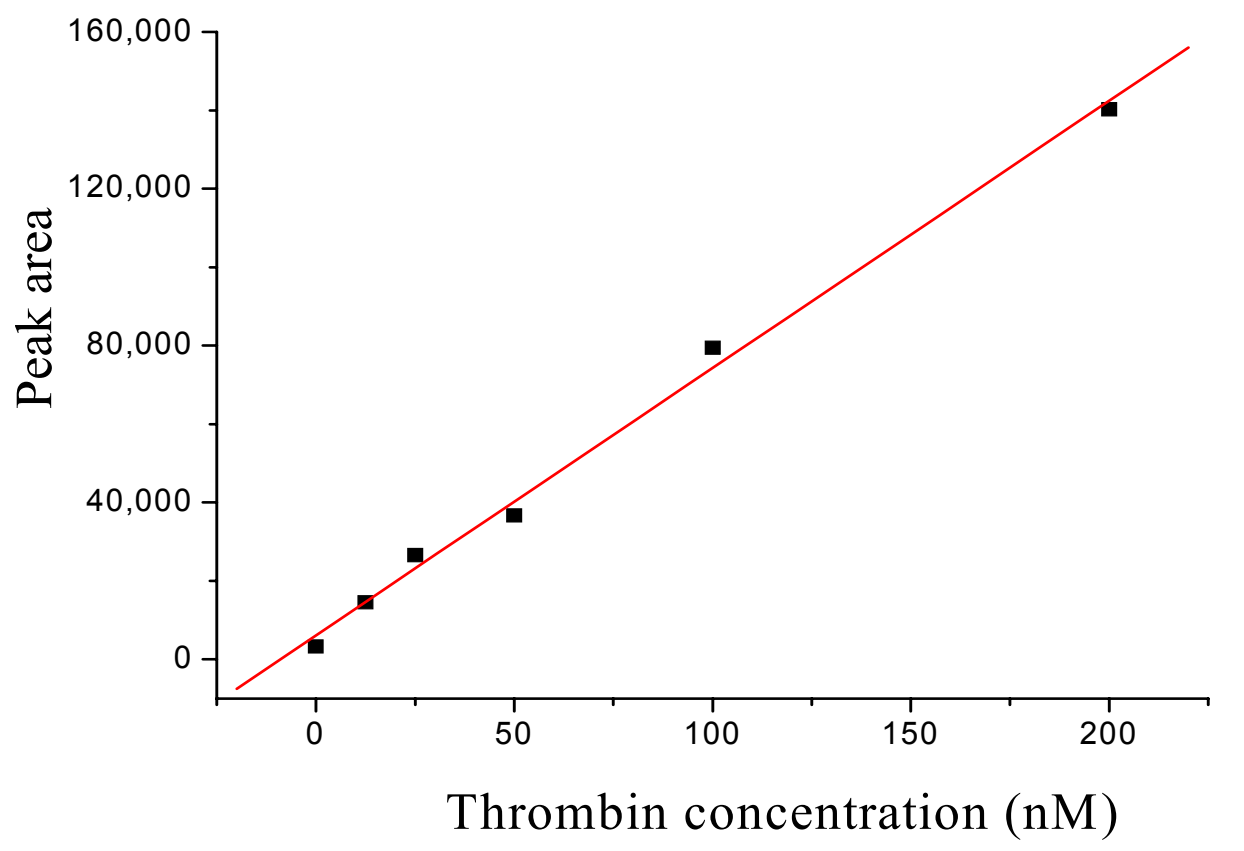

Figure S7. Results of thrombin assay by capillary electrophoresis. (a). Capillary electrophoregrams of thrombin-aptamer complexes and free aptamer. 1: A mixture of $100 \mathrm{nM}$ thrombin incubated with $50 \mathrm{nM}$ F29-mer in the running buffer; 2: $50 \mathrm{nM} \mathrm{F29-mer} \mathrm{in} \mathrm{the} \mathrm{running} \mathrm{buffer;} \mathrm{and} \mathrm{3:} \mathrm{A} \mathrm{mixture} \mathrm{of} 100 \mathrm{nM}$ thrombin incubated with $50 \mathrm{nM} \mathrm{F} 29-$ mer in $2.5 \%(\mathrm{v} / \mathrm{v})$ human serum. The running buffer was $2 \times \mathrm{TG}$ 
(TG containing $25 \mathrm{mM}$ Tris and $192 \mathrm{mM}$ glycine, $\mathrm{pH} 8.5$ ), the separation voltage was $18 \mathrm{kV}$, and the injection was at 0.3 psi for 5 s. (b). The linear relationship between the peak area of the thrombin-F29mer complex and the concentration of thrombin. Calibration curve was obtained by using increased concentration of thrombin and fixed concentration of F29-mer at $50 \mathrm{nM}$ in $2.5 \%(\mathrm{v} / \mathrm{v})$ human serum. 


\section{Supporting Tables:}

Table S1. Recovery results of CEA and AFP immunoassays

\begin{tabular}{lccccc}
\hline & \multicolumn{2}{c}{ CEA } & & \multicolumn{2}{c}{ AFP } \\
\cline { 2 - 3 } \cline { 5 - 6 } & Sample 1 & Sample 2 & & Sample 1 & Sample 2 \\
\hline Original amount (M) & $1.51 \times 10^{-13}$ & $1.51 \times 10^{-13}$ & & $2.74 \times 10^{-12}$ & $2.74 \times 10^{-12}$ \\
Added amount (M) & $2.60 \times 10^{-13}$ & $2.60 \times 10^{-12}$ & & $2.86 \times 10^{-12}$ & $2.86 \times 10^{-11}$ \\
Founded amount (M) & $3.9 \times 10^{-13}$ & $2.62 \times 10^{-12}$ & & $5.39 \times 10^{-12}$ & $2.88 \times 10^{-11}$ \\
Recovery (\%) & 91.9 & 95.0 & & 92.7 & 91.1 \\
RSD (\%) & 9.3 & 6.0 & & 6.9 & 7.8 \\
\hline
\end{tabular}

In recovery experiments, a given amount of antigens (CEA and AFP) were added into the sample 6 after sample was 200 times diluted with buffer. The samples were then measured by SGNPC. The RSD was obtained from three independent experiments. 


\section{Supporting Video:}

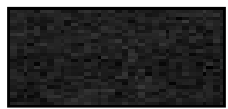

The movie of GNPs photon bursting in solution. Please click the image to start the movie. Images $(7.8 \times$ 3.6 $\mu \mathrm{m}^{2}$ ) were obtained without a pinhole using an electron-multiplying charge-coupled device (EMCCD) camera with a frame-transfer device (Cascade 650, Photometrics, USA). The frame transfer device has an imaging array of $653 \times 492$ with $7.4 \times 7.4 \mu \mathrm{m}^{2} /$ pixel. The play rate was 30 frames/s with $2 \mathrm{~ms}$ exposure time for each frame. Scale bar was $2 \mu \mathrm{m}$, GNPs $(36 \mathrm{~nm})$ concentration was $1.7 \times 10^{-10} \mathrm{M}$, and laser illumination power was $0.1 \mathrm{~mW}$. 


\section{Complete reference. 1}

(1) Loos, R. J. F.; Lindgren, C. M.; Li, S.; Wheeler, E.; Zhao, J. H.; Prokopenko, I.; Inouye, M.;

Freathy, R. M.; Attwood, A. P.; Beckmann, J. S.; Berndt, S. I.; Jacobs, K. B.; Chanock, S. J.; Hayes, R. B.; Bergmann, S.; Bennett, A. J.; Bingham, S. A.; Bochud, M.; Brown, M.; Cauchi, S.; Connell, J. M.; Cooper, C.; Smith, G. D.; Day, I.; Dina, C.; De, S.; Dermitzakis, E. T.; Doney, A. S. F.; Elliott, K. S.; Elliott, P.; Evans, D. M.; Sadaf Farooqi, I.; Froguel, P.; Ghori, J.; Groves, C. J.; Gwilliam, R.; Hadley, D.; Hall, A. S.; Hattersley, A. T.; Hebebrand, J.; Heid, I. M.; Lamina, C.; Gieger, C.; Illig, T.; Meitinger, T.; Wichmann, H. E.; Herrera, B.; Hinney, A.; Hunt, S. E.; Jarvelin, M. R.; Johnson, T.; Jolley, J. D. M.; Karpe, F.; Keniry, A.; Khaw, K. T.; Luben, R. N.; Mangino, M.; Marchini, J.; McArdle, W. L.; McGinnis, R.; Meyre, D.; Munroe, P. B.; Morris, A. D.; Ness, A. R.; Neville, M. J.; Nica, A. C.; Ong, K. K.; O'Rahilly, S.; Owen, K. R.; Palmer, C. N. A.; Papadakis, K.; Potter, S.; Pouta, A.; Qi, L.; Kraft, P.; Hankinson, S. E.; Hunter, D. J.; Hu, F. B.; Randall, J. C.; Rayner, N. W.; Ring, S. M.; Sandhu, M. S.; Scherag, A.; Sims, M. A.; Song, K.; Soranzo, N.; Speliotes, E. K.; Lyon, H. N.; Voight, B. F.; Ridderstrale, M.; Groop, L.; Syddall, H. E.; Teichmann, S. A.; Timpson, N. J.; Tobias, J. H.; Uda, M.; Scheet, P.; Sanna, S.; Abecasis, G. R.; Albai, G.; Nagaraja, R.; Schlessinger, D.; Ganz Vogel, C. I.; Wallace, C.; Waterworth, D. M.; Weedon, M. N.; Willer, C. J.; Jackson, A. U.; Tuomilehto, J.; Collins, F. S.; Boehnke, M.; Mohlke, K. L.; Wraight, V. L.; Yuan, X.; Zeggini, E.; Hirschhorn, J. N.; Strachan, D. P.; Ouwehand, W. H.; Caulfield, M. J.; Samani, N. J.; Frayling, T. M.; Vollenweider, P.; Waeber, G.; Mooser, V.; Deloukas, P.; McCarthy, M. I.; Wareham, N. J.; Barroso, I. Nat. Genet. 2008, 40, 768-775. 